\title{
OBSERVATIONS ON THE MILK OF NEW ZEALAND WOMEN
}

\author{
BY \\ HELEN EASTERFIELD DEEM, M.D., \\ Lady Truby King Scholar in the University of Otago, N.Z.
}

\section{PART I. THE DIURNAL VARIATION IN THE FAT CONTENT OF HUMAN MILK.}

The composition of human milk has been the subject of many researches but reference to the literature indicates that little attention has been paid to the question of diurnal variation in the fat content of the milk. No definite approach to regularity in this variation has hitherto been observed.

Reiset $^{1}$ as far back as 1849 observed that the fat parcentage of human milk was decreased and the amount of milk increased by extending the time between successive milkings. Helbich² from the examination of the milk of six wet nurses concluded that the fat percentage of human milk expressed at four-hourly intervals was highest at 10 a.m. and 2 p.m. Talbot ${ }^{3}$ from the examination of the milk of six women concluded that the fat percentage of milk expressed at three-hourly intervals was highest at noon or later on in the day. The data submitted show, however, that two of his six cases did not support his conclusion. Myers ${ }^{4}$ records the analysis of the milk of three women whose breasts were expressed at different times of the same day; variations in the composition were noticed and the paper is concluded with an apt quotation of John Thomson 'that the composition of human milk, like other secretions, varies from time to time and even during the course of the day.'

The object of the present investigation was to record, under rigidly controlled conditions, the limits in the diurnal variation in the fat percentage of the milk of a large number of women in order that any regularity of variation might become apparent. In such an enquiry meticulous attention must be paid to the collection of the samples which are to form the basis of the research, for, unless the samples are carefully taken under strictly comparable conditions, the deductions must be open to question however carefully analysis of the samples is carried out. Additional precautions are needed in investigating human milk because of the recognized influence of psychological factors.

For the collection and analysis of the samples employed in the research the following conditions were postulated :-

(a) The women must be healthy and well nourished, and must have a fairly abundant milk secretion.

(b) The milk in any one experiment must be expressed by the same operator at regular intervals. 
(c) The greatest care must be taken to avoid loss of fore milk by leakage, and that the after milk or "strippings" should be expressed as completely as possible.

(d) The mother should be kept in a contented state of mind, by cheerful talk and sympathy, during the whole process of expression.

All samples of milk were expressed either by the writer or, as in Series 4, under the personal supervision of the writer. The precautions taken in procuring the samples are dealt with in the experimental part of the paper.

Four separate series of experiments were carried out during the past eighteen months and the diurnal variations in the fat content of the milk of thirty women were recorded. This has involved the determination of the fat percentage of 332 samples.

Eighty-one samples were analysed completely for fat, protein, sugar and ash, in order to determine the question of diurnal variation in the constituents other than fat.

The diurnal variation in the fat content of the milk of four women was determined on seven different days, one week elapsing between each experiment. The results are expressed graphically in Graph III.

In 27 cases, the milk was expressed from one breast only throughout the day. In three cases, the milk of both breasts was expressed separately and the samples independently analysec'.

The mothers from whom the samples were taken were healthy, well nourished women of European stock. With two exceptions, all were born in New Zealand. Their ages ranged from 17 to 38 years, but 5 only were above the age of 28 years. The mothers included in the first three series were temporary residents of the Karitane Home, Dunedin. Those included in the fourth series were, with one exception, residents of St. Mary's Home (for unmarried motherz), Otahuhu, Auckland, N.Z.

The infants were, with the exception of one case of pyloric stenosis, healthy and thriving on their mothers' milk. Their ages ranged from $\check{5}$ to 36 weeks. Four of the babies received a small complement of modified cow's milk; the remainder were adequately suckled by their mothers.

It is commonly stated that fore milk has a much lower fat percentage than end milk or strippings. Analyses made during this investigation bear out this contention. Care was therefore always taken to empty the breasts as completely as possible. It is assumed that some milk remained in the deeper recesses of the mammæ at the end of expression, for Gaines ${ }^{5}$ who conducted a series of careful experiments on goats proved that hand milking did not empty the goat's udder as efficiently as did the suction of the kid, but he concluded that hand milking ensured a uniform degree of emptying at each milking. Similarly, the writer contends that when hand expression is done by one experienced individual an uniform degree of emptying will take place at each expression.

Great attention was paid to the psychological factor for it is generally recognized amongst farmers that even in cattle the holding back of the milk 
will take place if the animal is not completely at its ease. The same psychological factor is by no means uncommon amongst nervous and excitable nursing mothers ; hence a practice was invariably made of securing the confidence and friendship of the mother before taking a sample of her milk.

It was found that the large flat muscular type of breast could not be emptied effectively by manual expression, and for this reason samples were not taken from women with this type of breast.

Method of investigation.--The milk was obtained from the breast by hand expression in the following manner. The breast was grasped at the proximal boundary of the areola by thumb and fore-finger of the operator's right hand; the left hand was used to steady the breast. Each pressure of the fingers was accompanied by a downward and forward movement without any manipulation or squeezing of mammary tissue. The milk flowed freely from the breast in a series of jets.

During the course of an experiment, the infant of the mother in question was allowed one breast only throughout the 24-hour period of the experiment, and was weighed before and after going to that breast. When the infant had been fed from one breast, the entire content of the other was expressed, well mixed, and a sample taken for analysis. The remainder of the milk was given to the baby by bottle. In general, the quantity of milk obtained by expression was less than the amount obtained directly from the breast by the baby. This is in accordance with Gaines's results already mentioned. In each case the amount of milk obtained by the baby indicated the amount of milk that might be expected as the result of expression. In some instances, where the flow had apparently ceased and yet the amount of milk expressed was considerably less than had been obtained by the baby, a rest for a minute or two, together with gentle stroking of the breast, again produced a free flow of milk. Had not this after milking been carried out, the richest portion of the milk would have been missed and a grave error would have been introduced.

Women with an abundant milk secration frequently stated that when the infant commenced to suck from one breast, at the 6 a.m. feeding in particular, the milk simultaneously leaked away from the other breast. This statement was confirmed by personal observation, and it is in accordance with the observations of Gaines on the mechanism of milk secretion in lactating animals. Care was therefore taken to collect all milk which leaked away from the one breast as a result of the general stimulus to milk flow provided by the sucking of the child at the other breast. Thus no fore milk was lost.

In order to give a mother confidence and at the same time assure her that the process of expression was simple and not painful, one breast was expressed as completely as possible at the feeding time before the actual experiment was commenced. Succeeding specimens were then obtained at four-hourly* intervals during the day, with an eight-hour interval during the night. Five specimens were thus obtained at the usual feeding times, 6 a.m., 10 a.m., 2 p.m., 6 p.m. and 10 p.m.

*In 3 cases, the specimens were obtained at three-hourly intervals throughout the day, commencing at 6 a.m. 
Four separate series of observations were made. In the first three series, every sample of milk, with one exception, was expressed by the writer. In the fourth, the mothers, who were all skilled expressors, did their own expressing under the supervision of the writer. In this series the final expression took place a.t 11 p.m. after the mothers had had between two and three hours' sleep.

Analysis.-Four separate series of analyses were made.

I. In the first series the author determined, by the Babcock method, the percentage of fat in thirty samples of milk expressed by herself from six women at the four-hourly intervals. The mean curve for the diurnal variation of Series 1, as shown in Graph I, was sufficiently striking to demand confirmation by other series of experiments in which the analyses were conducted by independent observers.

II. In the second series (comprising 7 individual cases) the diurnal variation in the fat and other constituents of the milk was determined. Complete analyses of 81 samples of human milk were made by the Dunedin Government analyst, Mr. L. S. James, M.Sc., F.I.C.

III. In the third series (8 cases) the fat only was determined. This also was done by $\mathrm{Mr}$. L. S. James.

IV. In the fourth series (9 cases) the analyses were carried out by Mr. K. M. Griffen, M.Sc., F.I.C., Auckland Government analyst, and only fat determinations were made except in special cases where the effect of diet on milk production was being studied.

In the analyses conducted by the Government analysts the fat was determined by the Gerber process; the protein by the Kjeldahl method; the ash by incineration; and the sugar by difference.

Average fat.-Since the weight of milk obtained is not the same at each expression, the average percentage of fat on one day is not identical with the arithmetical mean of the five fat percentages recorded on that day. The average percentage of fat in the day's milk is obviously found by dividing the total weight of the fat by the total weight of the milk expressed and multiplying by 100. The averages in the annexed tables are calculated on this basis.

\section{Results.}

The results of the investigation are given in the following tables and graphs.

TABLE 1.--Series I--IV, showing the diurnal variation in the fat content of the milk of twenty-seven women expressed at four-hourly intervals.

TABLe 2.- Showing the diurnal variation in the fat content of the milk of three women expressed at three-hourly intervals.

TABLE 3.--Showing the diurnal variation in the constituents of the milk other than fat.

GRAPH I.--Showing the mean curves for the diurnal variation in the fat content of the milk of each series.

GRAPH II.-Showing the average curves of diurnal variation of all the series in respect to fat content and volume. 
TABLE 1.

Showing THE DiURNaL Variation IN THE Fat content of THE MiLK OF TWENTY-SEVEN WOMEN.

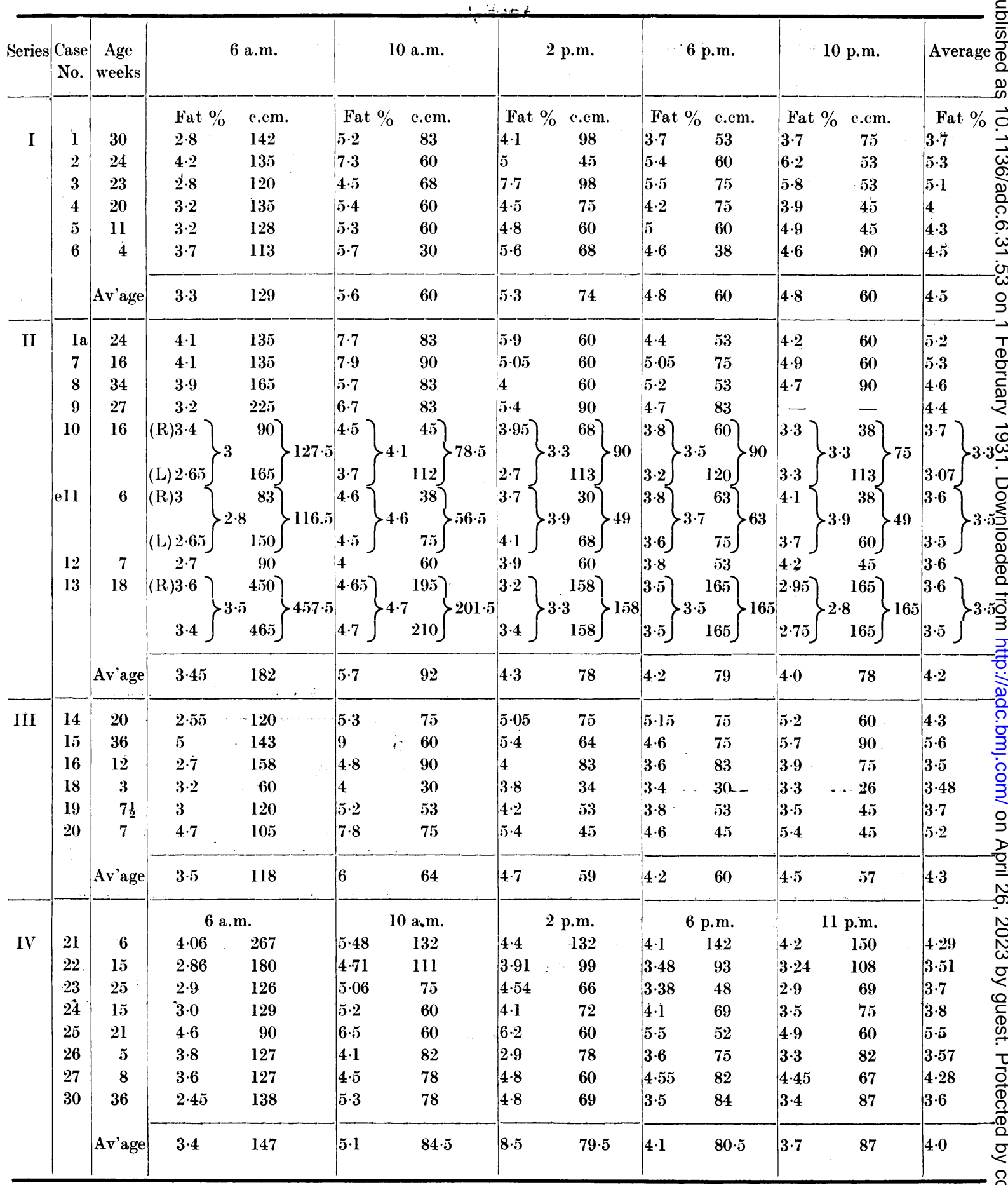


TABLE :.

SHOWING THE DILRNAL VARIATIO IN THE FAT COXTENT OF THE MILK OF THREE WOMEN EXPRESSED AT THREE-HOERIY INTERVALS.

\begin{tabular}{|c|c|c|c|c|c|c|c|c|c|c|c|c|c|}
\hline ('ase No. & 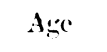 & \multicolumn{2}{|c|}{$6 \mathrm{a} . \mathrm{m}$. } & \multicolumn{2}{|c|}{$9 \mathrm{a} . \mathrm{m}}$. & \multicolumn{2}{|c|}{12 noon } & \multicolumn{2}{|c|}{3 p.m. } & \multicolumn{2}{|c|}{6 p.m. } & \multicolumn{2}{|c|}{9 p.m. } \\
\hline \multirow[b]{2}{*}{17} & \multirow[b]{2}{*}{$3 !$} & \multicolumn{2}{|c|}{ Fat $\%(\cdot c m$. } & \multicolumn{2}{|c|}{ Fat $\%(c \cdot c m}$. & \multicolumn{2}{|c|}{ Fat $\%$ c.cm. } & \multicolumn{2}{|c|}{ Fat $\%$ c.cm. } & \multicolumn{2}{|c|}{ Fat $\% \mathrm{cecm}$. } & \multicolumn{2}{|c|}{ Fat $\%$ c.cm. } \\
\hline & & $3 \cdot 2$ & $16 \pi$ & $5 \cdot 8$ & 82 & $4 \cdot 2$ & 67 & $4 \cdot 3$ & 82 & $4 \cdot 2$ & 60 & $4 \cdot 1$ & 60 \\
\hline $28 *$ & (j) & $2 \cdot 9$ & 105 & $4 \cdot 1$ & 52 & $3 \cdot 4$ & 45 & $4 \cdot 0$ & 56 & $2 \cdot 7$ & 45 & $3 \cdot 4$ & 75 \\
\hline \multirow[t]{2}{*}{$29 *$} & 4 & $3 \cdot 6$ & 1.56 & $4 \cdot 9$ & 84 & $3 \cdot 8$ & 72 & $3 \cdot 3$ & 63 & $3 \cdot 3$ & 57 & $3 \cdot 4$ & 66 \\
\hline & Average & $3 \cdot 2$ & $14: 2$ & $4 \cdot 9$ & $72 \cdot 6$ & $3 \cdot 8$ & $(61 \cdot 3$ & $3 \cdot 9$ & 67 & $3 \cdot 4$ & $\pi 4$ & $3 \cdot 6$ & 67 \\
\hline
\end{tabular}

* In (ases 28 and 29 the last expression took place at 11 p.m. This probably accountr for the comparatively large volume expressed after a five-hour interval of rest.

TABLE 3.

SHOWING THE DILRNAL VARIATION IN THE CONSTITLENTS O'THER THAX FAT OF THE MILK OF SEVEN WOMES.

\begin{tabular}{|c|c|c|c|c|c|c|c|c|c|c|c|c|c|c|c|c|c|c|c|}
\hline \multirow[t]{2}{*}{$\begin{array}{l}\text { Case } \\
\text { No. }\end{array}$} & \multicolumn{3}{|c|}{6 a.m. } & \multicolumn{4}{|c|}{10 a.m. } & \multicolumn{4}{|c|}{2 p.m. } & \multicolumn{4}{|c|}{6 p.m. } & \multicolumn{4}{|c|}{10 p.m. } \\
\hline & $\frac{3}{0}$ & 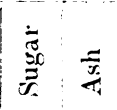 & 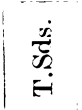 & 竞 & 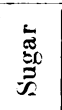 & $\frac{2}{7}$ & 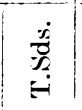 & 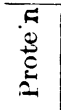 & 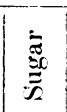 & $\underset{\sim}{-1}$ & 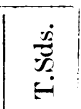 & 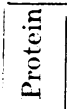 & 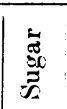 & $\frac{\pi}{4}$ & $\begin{array}{l}\frac{\dot{3}}{8} \\
\vec{n} \\
\dot{H}\end{array}$ & $\left|\begin{array}{l}0 \\
0 \\
0 \\
0 \\
0 \\
0\end{array}\right|$ & 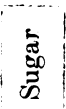 & $\frac{5}{4}$ & $\begin{array}{l}\dot{2} \\
\dot{B} \\
\dot{H}\end{array}$ \\
\hline la & 1.06 & $\begin{array}{lll}7 \cdot 37 & \cdot 18\end{array}$ & 12.71 & $1 \cdot 17$ & $7 \cdot 3$ & $\cdot 19$ & $16 \cdot 36$ & $1 \cdot 0 \tilde{5}$ & $7 \cdot 17$ & $\cdot 19$ & $14 \cdot 31$ & $1 \cdot 12$ & $7 \cdot 3$ & $\cdot 19$ & 12.96 & 1.09 & $7 \cdot 37$ & $\cdot 19$ & $12 \cdot 85$ \\
\hline 7 & $1 \cdot 21$ & $7 \cdot 17 \cdot 19$ & 12.72 & $1 \cdot 26$ & $7 \cdot 09$ & $\cdot 21$ & $16 \cdot 46$ & $1 \cdot 23$ & $7 \cdot 26$ & .2 & $13 \cdot 74$ & $1 \cdot 14$ & $7 \cdot 12$ & $\cdot 19$ & $13 \cdot 5$ & $1 \cdot 13$ & $7 \cdot 12$ & $\cdot 2$ & $13 \cdot 35$ \\
\hline 8 & 1.06 & $6.57 \cdot 17$ & 11.7 & 1.06 & $6 \cdot 89$ & $\cdot 18$ & 13.83 & $1 \cdot 10$ & $7 \cdot 13$ & $\cdot 17$ & $12 \cdot 4$ & $1 \cdot 12$ & $7 \cdot 38$ & $\cdot 2$ & $13 \cdot 9$ & 1.07 & $7 \cdot 36$ & $\cdot 2$ & $13 \cdot 33$ \\
\hline $9^{*}$ & 1.09 & $7 \cdot 36 \cdot \cdot 19$ & $11 \cdot 79$ & $1 \cdot 15$ & $7 \cdot 04$ & $\cdot 18$ & 15.07 & $1 \cdot 11$ & $7 \cdot 15$ & $\cdot 19$ & $13 \cdot 8$ & $1 \cdot 11$ & $7 \cdot 31$ & $\cdot 19$ & $13 \cdot 3$ & - & - & - & - \\
\hline & $1 \cdot 59$ & 6.85 .25 & 12.09 & $1 \cdot 59$ & $6 \cdot 9$ & $\cdot 25$ & $13 \cdot 24$ & $1 \cdot 62$ & $7 \cdot 33$ & $\cdot 24$ & $13 \cdot 14$ & $1 \cdot 64$ & 7.09 & $\cdot 27$ & 12.8 & $1 \cdot 63$ & $7 \cdot 17$ & $\cdot 26$ & 12.61 \\
\hline $\mathrm{L}$ & $1 \cdot 23$ & $6 \cdot 49 \cdot 21$ & $11 \cdot 58$ & $1 \cdot 23$ & $7 \cdot 33$ & 21 & $12 \cdot 47$ & $1 \cdot 21$ & $7 \cdot 57$ & $\cdot 21$ & $11 \cdot 69$ & $1 \cdot 19$ & $7 \cdot 42$ & $\cdot 22$ & 12.03 & $1 \cdot 27$ & $7 \cdot 32$ & $\cdot 22$ & $12 \cdot 11$ \\
\hline 11 & $1 \cdot 25$ & $7 \cdot 47 \cdot 2$ & $11 \cdot \tilde{5} 7$ & $1 \cdot 39$ & $7 \cdot 11$ & .21 & $13 \cdot 21$ & $1 \cdot 35$ & $7 \cdot 23$ & .21 & $12 \cdot 89$ & $1 \cdot 34$ & $7 \cdot 39$ & $\cdot 2$ & $12 \cdot 58$ & $1 \cdot 25$ & $7 \cdot 22$ & .2 & $12 \cdot 37$ \\
\hline 13 & $1 \cdot 15$ & $7 \cdot 39 \cdot \cdot 18$ & $12 \cdot 32$ & $1 \cdot 14$ & $7 \cdot 25$ & $\cdot 18$ & $13 \cdot 2 \cdot 2$ & $1 \cdot 10$ & $7 \cdot 29$ & $\cdot 18$ & $11 \cdot 77$ & $1 \cdot 02$ & $7 \cdot 41$ & $\cdot 19$ & $12 \cdot 12$ & 1.09 & $7 \cdot 31^{:}$ & $\cdot 19$ & $11 \cdot 54$ \\
\hline & $1 \cdot 13$ & $7 \cdot 54 \cdot 19$ & $12 \cdot 26$ & $1 \cdot 15$ & $7 \cdot 26$ & $\cdot 19$ & $13 \cdot 3$ & $1 \cdot 11$ & $7 \cdot 41$ & $\cdot 19$ & $12 \cdot 11$ & 1.08 & $7 \cdot 35$ & $\cdot 19$ & $12 \cdot 12$ & 1.09 & $7 \cdot 43$ & $\cdot 18$ & $11 \cdot 14$ \\
\hline
\end{tabular}

* child fed 4 times in 24 hours. 


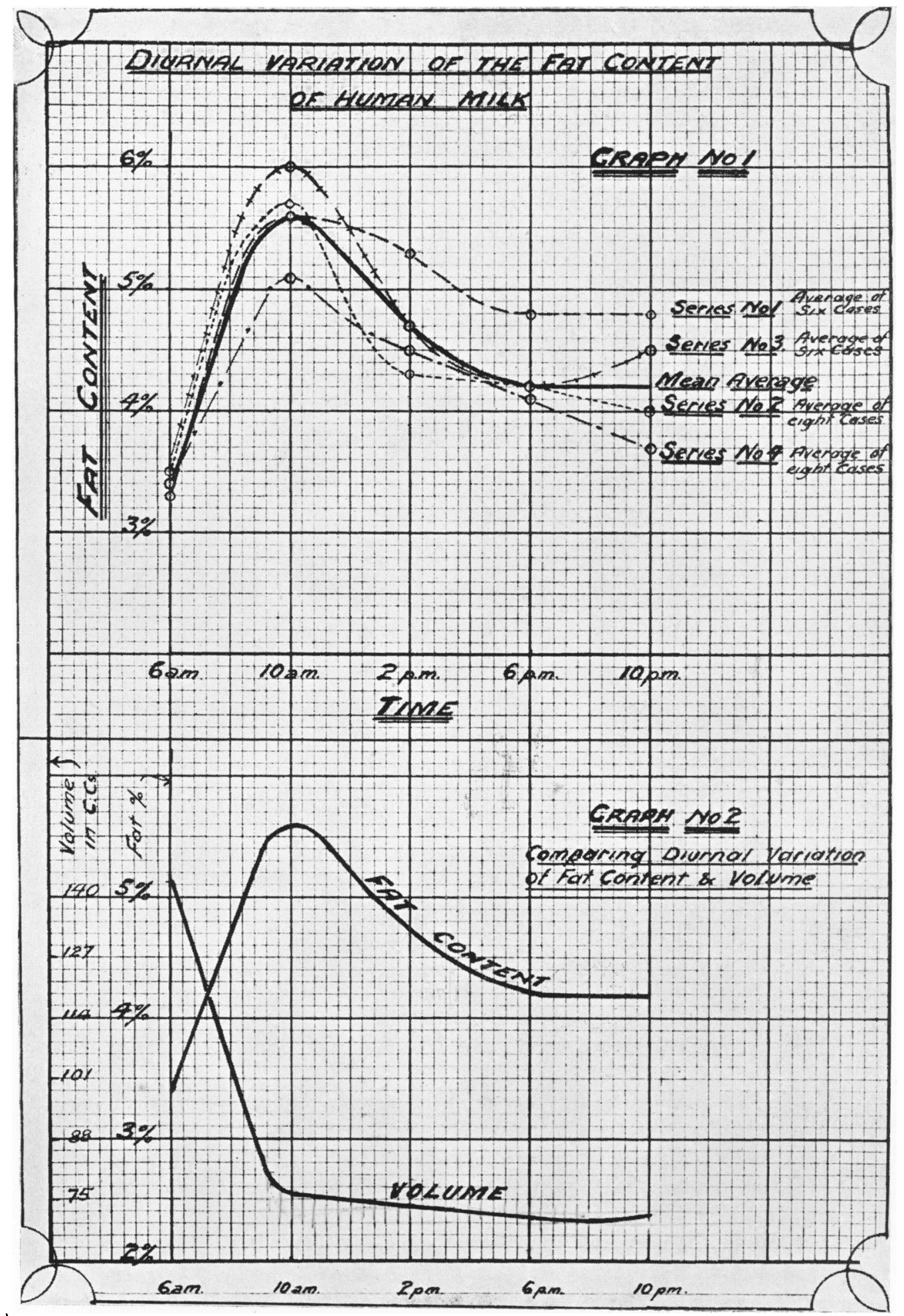

GraphS I \& II. 


\section{Discussion of results.}

The average fat percentage for the day was between 3 and 4 in 16 cases (53.3 per cent.); between 4 and 5 in 8 cases ( 26.7 per cent.); and above 5 in 6 cases ( 20 per cent.).

The mean average fat percentage was $4 \cdot 18$. This figure is higher than that given by Richmond ${ }^{6}$ but is lower than that given by various continental writers. It must be noted, however, that 53.3 per cent. of the cases investigated showed an average fat percentage between 3 and 4 .

The highest average fat percentage for the day was $5 \cdot 4$, and the lowest $3 \cdot 2$. The highest fat percentage of a single sample was 9 , and the lowest $2 \cdot 1$.

The milks with the high average fat content showed the greatest diurnal variation ; one case showed a difference of 4.9 per cent. between the highest and lowest values for the day.

Four of the six children receiving milk containing over jo per cent. of fat were afflicted with infantile eczema ; they were, however, all thriving well on their mothers' milk, one case (Case 15 ) being $4 \mathrm{lb}$. above the average weight of a child the same age (9 months).

The highest protein in a single sample was 1.64 per cent. and the lowest . 8 per cent.* The child, who was receiving the milk with the low protein content ( 8 per cent.) was $4 \mathrm{lb}$. below the average weight of a child of the same age $\left(9 \frac{1}{4}\right.$ months $)$.

The average protein percentage of the milk of the cases investigated was 1.2. This figure agrees with that given by Richmond.

The highest ash in a single sample was $\cdot 27$ per cent. and the lowest $\cdot 17$ per cent.

In every case the largest volume of milk obtained at a single expression was recorded at 6 a.m. The average volume obtained at the specified times are recorded in Graph II. The largest volume expressed from a subject during the twenty-four hour period was $2,355 \mathrm{c} . \mathrm{cm}$. This amount was obtained from the two breasts of a mother of twins.

In Series I the highest fat percentage for the day was found at $10 \mathrm{a}$ a.m. in five of the six cases investigated. The lowest fat percentage for the day was found at 6 a.m. in all of the six cases.

In Series II the highest fat percentage for the day was found at $10 \mathrm{a} . \mathrm{m}$. in seven of the eight cases investigated. The lowest fat percentage for the day was found at 6 a.m. in seven of the eight cases.

In Series III the highest fat percentage for the day was found at 10 a.m. in all of the cases investigated. The lowest fat percentage for the day was found at 6 a.m. in five of the six cases.

In Series IV the highest fat percentage for the day was found at $10 \mathrm{a} . \mathrm{m}$. in seven of the eight cases investigated. The lowest fat percentage for the day was found at 6 a.m. in seven of the eight cases.

Thus in 24 of the. 27 cases investigated (i.e., 89 per cent.) the highest fat percentage for the day was found at $10 \mathrm{a} . \mathrm{m}$. and in twenty-four of the cases investigated the lowest fat percentage for the day was found at 6 a.m.

*'The mother, who produced the milk of such low protein content, was a strict vegetarian who absolutely excluded animal protein from her diet. Her protein ration was obtained almost entirely from whole-meal bread and peanuts-of the latter she consumed $6 \cdot 20 \mathrm{z}$. daily. 
The average diurnal variation for each series and the average variation for all cases is represented graphically in Graph I.

In the three cases investigated, where the milk was expressed at threehourly intervals throughout the day commencing at $6 \mathrm{a} . \mathrm{m}$., the fat percentage was found to be highest at $9 \mathrm{a} . \mathrm{m}$. in all three cases.

No diurnal variation in the constituents of the milk other than fat was observed.

The foregoing results and the graphs traced from them indicate the existence of a definite diurnal variation in the fat content of human milk. In the opinion of the writer, the results warrant the enunciation of the following law :-

If all precautions are taken to secure the fore milk, middle milk and end milk present in the human breast, and if expression takes place at regular four-hourly intervals from 6 a.m. until 10 p.m., the fat percentage is in general lowest at 6 a.m., highest at 10 a.m., high at 2 p.m. and decreases as the day advances.

When it is borne in mind that physiological functions tend to show irregularities due to psychological, digestive, and other disturbances, as well as those characteristic of the individual subject, it is surprising that as much evidence of the existence of a general law has been observed. It is, however, obvious that the general rule or law of diurnal variation of fat content of human milk should not be accepted as a general application until it has been carefully tested by other observers working on a much larger number of rigidly controlled cases. It is also clear, when it is seen how great the diurnal variation in the fat content of human milk can be, that deductions based on the analyses of milk expressed at one time of the day only must be liable to very grave error.*

\section{Summary of Part I.}

(1) The diurnal variation in the fat content of the milk of thirty New Zealand women has been investigated.

(2) The results indicate that it usually takes place according to the following law :-..

If all precautions are taken to secure the fore milk, middle milk and end milk present in the human breast, and if expression takes place at regular four-hourly intervals from 6 a.m. until 10 p.m., the fat percentage is in general lowest at 6 a.m., highest at 10 a.m., high at 2 p.m. and decreases as the day advances.

(3) No diurnal variation in the constituents of human milk other than fat was observed.

(4) The mean average composition of the milk of the women investigated was:--fat $4 \cdot 18$ per cent., protein $1 \cdot 2$ per cent., ash $\cdot 2 \cdot 2$ per cent., and sugar 7.21 per cent. In 53.3 per cent. of the cases, the fat percentage was between 3 and 4 , the average of these cases being $3 \cdot 57$.

(5) The importance of a knowledge of the law of diurnal variation is emphasized.

* Probably the high figure given by Wardlan and Dart ${ }^{7}$ for the average fat percentage of the milk of Aistralian women is due in part to the fact that all samples of milk were expressed at 10 a.m. 


\section{PART II. THE EFFECT OF DIET ON THE SECRETION OF HUMAN MILK.}

The object of the present investigation was to determine the effect of diet on the secretion of human milk.

The effect of diet upon the milk production of the cow is a problem which is constantly engaging the attention of dairy scientists. The results obtained by many workers in this field are contradictory, but with reference to certain findings a general opinion is entertained. Meigs ${ }^{8}$ gives a comprehensive review of the subject and concludes that protein stimulates milk secretion and thus increases milk yield, and that the composition of milk may be affected by the feeding of certain diets.

With reference to the effect of diet on human milk production, the text-books in general state that provided the diet of a nursing mother is adequate, changes in any one of the food 'onstituents of the diet will not appreciably affect the quality or quantity of her milk. Reference to the original literature shows that all too little work has been done on this important subject.

Enge ${ }^{9}$ maintained that provided there was an adequate amount $\mathrm{cf}$ fat in the diet of the nursing mother, an increase in the fat content of the diet did not increase the fat percentage of her milk. ('zerny and Keller ${ }^{10}$ conclude that the milk of nursing mothers cannot be permanently influenced by the food except in those instances when they are partially starved. Hoobler ${ }^{11}$ investigated the effect of diet on the quality and quantity of the milk of two women. He concluded that a diet of a caloric value between $2,400-2,900$ calories with a protein ratio of $1: 4$ was optimum diet for a nursing mother. He also concluded that animal protein in the diet was superior to vegetable protein. Bell ${ }^{12}$ added small quantities of rice, tapioca or cream to a usual hospital diet and fed some mothers on one diet and others on another. She concluded from her experiments that the different diets given had little effect upon the composition of the milk.

The present work was carried out at St. Mary's Home, Auckland, N.Z. The mothers were taken into the home on the understanding that they were to reside there for six months after the birth of their infants and they were encouraged in every way to breast feed during the entire period. The Institution food was plain, wholesome and plentiful. The mothers appeared to have excessive appetites, a fact which is not surprising as they did all the manual labour of the home, such as milking cows, washing clothes, scrubbing floors and gardening.

As a routine practice, the mothers were taught the technique of hand expression during the puerperium. They became so proficient in the art that it was considered advisable in this investigation to allow them to express their own milk under supervision. Before selecting the special cases for the diet experiments, all the mothers in the home were carefully observed over a period of a fortnight. The diurnal variation in the fat content of the milk of each was estimated in the same way as detailed previously. These cases constitute Series IV in Part I of this paper.

As a result of these observations, it was possible to select suitable cases for the present investigation and five of the most trustworthy, keen and intelligent mothers were selected. Four of these were completely feeding their babies ; one with a slightly inadequate milk supply was chosen with the object of increasing her supply.

The mothers were healthy and active. Their ages ranged from 17 to 27 years. The infants were healthy and thriving, their ages ranging from 4 to 18 weeks. 
Methods of investigation.-The five mothers selected were subjected to seven consecutive weeks of dieting under strict supervision. The diets were given in the following sequence: (1) Institution (St. Mary's Home Diet), (2) High Protein, (3) Institution, (4) High Protein + Vitamin B*, (5) High Sugar, (6) High Fat, (7) Low Protein. Each mother was fed for a period of 7 days on a specific diet. The food consumed by her was weighed and then calculated in terms calories, protein, fat and carbohydrate. It was not possible to revert to the Institution diet after each special period of dieting without unduly prolonging the duration of the whole experiment.

For 6 days, the babies were fed from both breasts at four-hourly intervals during the day and at eight-hourly intervals during the night, and test-weighed. Any milk remaining in the breast after feeding was expressed and measured.

On the 7th day, after 6 days' observation on a specific diet, the baby was fed from one breast only throughout the twenty-four hour experimental period and test-weighed, and the other breast was emptied as completely as possible by hand expression and the volume of milk measured. Thus the total yield of milk in the twenty-four hours was obtained.

The fat percentage of each expression was estimated in order to observe the effect of diet on the diurnal variation in the fat content of the milk. The results are tabulated in Table 6 and expressed graphically in Graph III.

The sample of milk which was analysed for protein, ash, sugar and total solids was a mixture of samples taken from each of the five daily expressions.

The analyses were conducted by the Auckland Government analyst, Mr. K. M. Griffen, M.Sc., F.I.C. The protein was determined by the Kjeldahl method; the fat by the Gerber process ; the ash by incineration ; the sugar by difference. The actual average fat percentage of the daily yield was com. puted in the same way as detailed in Part I of this paper.

DiETs.-The caloric value of the Institution diet consumed by the mothers in question was in the vicinity of 3,000 calories. An attempt was therefore made to keep the caloric value of the test diets in the neighbourhood of 3,000 calories. This figure was unavoidably exceeded in Diets V and VI.

The protein content of the Institution diet was approximately $90 \mathrm{grm}$., therefore the protein of the test diets (other than the high and low protein diets) was kept approximately at the original amount.

According to the particular diet used, large increases in the protein, carbohydrate or fat constituents were employed.

The details of the diets of the mothers are tabulated in Table 4.

The mothers had vigorous appetites and found no difficulty in consuming the food set before them.

The effects of different diets on the milk secretion of the five mothers are tabulated in Tables 5 and 6.

*B. Sure ${ }^{13}$ experimenting with rats proved conclusively that the vitamin-B requirement of the lactating rat was considerably greater than for its mere growth. Vitamin-B (in the form of marmite) was therefore given to the nursing mother to ascertain whether its addition to the diet had any beneficial effect on human milk secretion. 
TABLE 4.

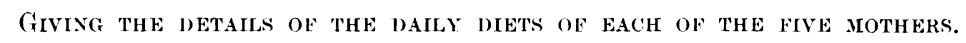

\begin{tabular}{|c|c|c|c|c|c|c|c|}
\hline Name & Diet & ('alories & $P:(+1-F$ & $\begin{array}{l}\text { Carbo- } \\
\text { hydrate }\end{array}$ & Fat & Protein & Remarks \\
\hline $\begin{array}{l}\text { Margaret } \\
\text { Daphne } \\
\text { Flossie } \\
\text { Mona } \\
\text { Nancy }\end{array}$ & 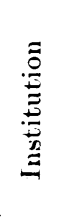 & $\begin{array}{l}3,168 \\
3,198 \\
3,082 \\
3,012 \\
3,201\end{array}$ & $\begin{array}{l}1: 7 \cdot 8 \\
1: 7 \cdot 7 \\
1: 7 \cdot 9 \\
1: 7 \cdot 8 \\
1: 7 \cdot 6\end{array}$ & $\begin{array}{l}\text { grm. } \\
469 \\
470 \\
4.50 \\
433 \\
468\end{array}$ & $\begin{array}{c}\text { grm. } \\
95 \\
97 \\
96 \\
96 \\
98\end{array}$ & $\begin{array}{c}\text { grm. } \\
88 \\
90 \\
84 \\
84 \\
91\end{array}$ & $\begin{array}{l}\text { Plain, wholesome diet. } \\
\text { large quantities of bread } \\
\text { and porridge; Puddings. }\end{array}$ \\
\hline $\begin{array}{l}\text { Margaret } \\
\text { Daphne } \\
\text { Flosicie } \\
\text { Mona } \\
\text { Nancy }\end{array}$ & 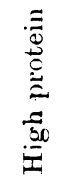 & $\begin{array}{l}3,069 \\
3,085 \\
3,932 \\
2,804 \\
3,152\end{array}$ & $\begin{array}{l}1: 4 \\
1: 4 \\
1: 4 \\
1: 3 \cdot 9 \\
1: 4\end{array}$ & $\begin{array}{l}410 \\
403 \\
372 \\
347 \\
408\end{array}$ & $\begin{array}{l}84 \\
88 \\
87 \\
87 \\
9.2\end{array}$ & $\begin{array}{l}148 \\
150 \\
143 \\
140 \\
152\end{array}$ & $\begin{array}{l}\text { This diet included } 3 \text { eggs, } \\
1,200 \mathrm{c} . \mathrm{cm} \text {. skimmed milk, } \\
180 \mathrm{grm} \text {. fish, } 120 \text { grm. } \\
\text { meat. }\end{array}$ \\
\hline $\begin{array}{l}\text { Margaret } \\
\text { Daphne } \\
\text { Flossie } \\
\text { Mona } \\
\text { Nancy }\end{array}$ & 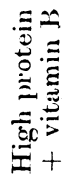 & $\begin{array}{l}2,944 \\
2,985 \\
2,886 \\
2,728 \\
2,952\end{array}$ & $\begin{array}{l}1: 3 \cdot 99 \\
1: 3 \cdot 9 \\
1: 3 \cdot 99 \\
1: 3 \cdot 8 \\
1: 3 \cdot 9\end{array}$ & $\begin{array}{l}379 \\
38 \pi \\
374 \\
337 \\
377\end{array}$ & $\begin{array}{l}86 \\
86 \\
84 \\
84 \\
86\end{array}$ & $\begin{array}{l}144 \\
148 \\
141 \\
138 \\
148\end{array}$ & $\begin{array}{l}\text { As above plus } 3 \text { grm. } \\
\text { marmite. }\end{array}$ \\
\hline $\begin{array}{l}\text { Margaret } \\
\text { *Daphne } \\
\text { Flossie } \\
\text { Mona } \\
\text { Nancy }\end{array}$ & 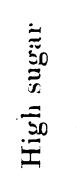 & $\begin{array}{l}3,836 \\
3,978 \\
3,935 \\
3,798 \\
4,001\end{array}$ & $\begin{array}{l}1: 9 \cdot 4 \\
1: 9 \cdot 5 \\
1: 9 \cdot 7 \\
1: 9 \cdot 7 \\
1: 9 \cdot 4\end{array}$ & $\begin{array}{l}630 \\
654 \\
646 \\
618 \\
656\end{array}$ & $\begin{array}{r}95 \\
99 \\
99 \\
98 \\
100\end{array}$ & $\begin{array}{l}90 \\
92 \\
89 \\
86 \\
93\end{array}$ & $\begin{array}{l}\text { This diet included } 90 \text { grm. } \\
\text { dates, } 30 \text { grm. raisins, } \\
60 \text { grm. jam, } 150 \text { grm. iced } \\
\text { cake, } 60 \text { grm. marsh } \\
\text { mallow sweet pudding. }\end{array}$ \\
\hline $\begin{array}{l}\text { Margaret } \\
\text { Daphne } \\
\text { Flossie } \\
\text { Mona } \\
\text { Nancy }\end{array}$ & 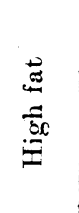 & $\begin{array}{l}4,430 \\
4,386 \\
3,995 \\
4,303 \\
4,461\end{array}$ & $\begin{array}{l}1: 10 \cdot 9 \\
1: 11 \\
1: 11 \\
1: 11 \cdot 4 \\
1: 10 \cdot 8\end{array}$ & $\begin{array}{l}411 \\
407 \\
375 \\
382 \\
420\end{array}$ & $\begin{array}{l}25.5 \\
253 \\
2.29 \\
265 \\
2.54\end{array}$ & $\begin{array}{l}91 \\
89 \\
80 \\
86 \\
92\end{array}$ & $\begin{array}{l}\text { This diet included } 150 \text { c.cm. } \\
\text { cream, 45 grm. bacon, } \\
30 \text { grm. fat ham, } 30 \text { grm. } \\
\text { butter, } 40 \text { grm. dripping, } \\
60 \text { grm. shortbread, suet } \\
\text { pudding or pastry. }\end{array}$ \\
\hline $\begin{array}{l}\text { Margaret } \\
\text { Daphne } \\
\text { Flossie } \\
\text { Mona } \\
\text { Nancy }\end{array}$ & $\begin{array}{l}\frac{\pi}{2} \\
\frac{1}{0} \\
\frac{1}{2} \\
\vdots \\
0\end{array}$ & $\begin{array}{l}2,848 \\
2,861 \\
2,779 \\
2,783 \\
2,862\end{array}$ & $\begin{array}{l}1: 10 \cdot 2 \\
1: 10 \cdot 2 \\
1: 10 \cdot 4 \\
1: 10 \cdot 3 \\
1: 10 \cdot 2\end{array}$ & $\begin{array}{l}354 \\
357 \\
340 \\
340 \\
357\end{array}$ & $\begin{array}{l}123 \\
123 \\
123 \\
123 \\
123\end{array}$ & $\begin{array}{l}62 \\
62 \\
59 \\
60 \\
62\end{array}$ & $\begin{array}{l}\text { This diet included much } \\
\text { green salads, pastry and } \\
\text { vegetable soup - inevit- } \\
\text { ably a comparatively high } \\
\text { fat diet. }\end{array}$ \\
\hline
\end{tabular}

* Average of 4 days diet : had bilious attack on fifth day. 
TABLE :̃.

EFEC'T OF DHFERENT DIETS ON THE MILK PRODCCTION OF FIVE MOTHERS.

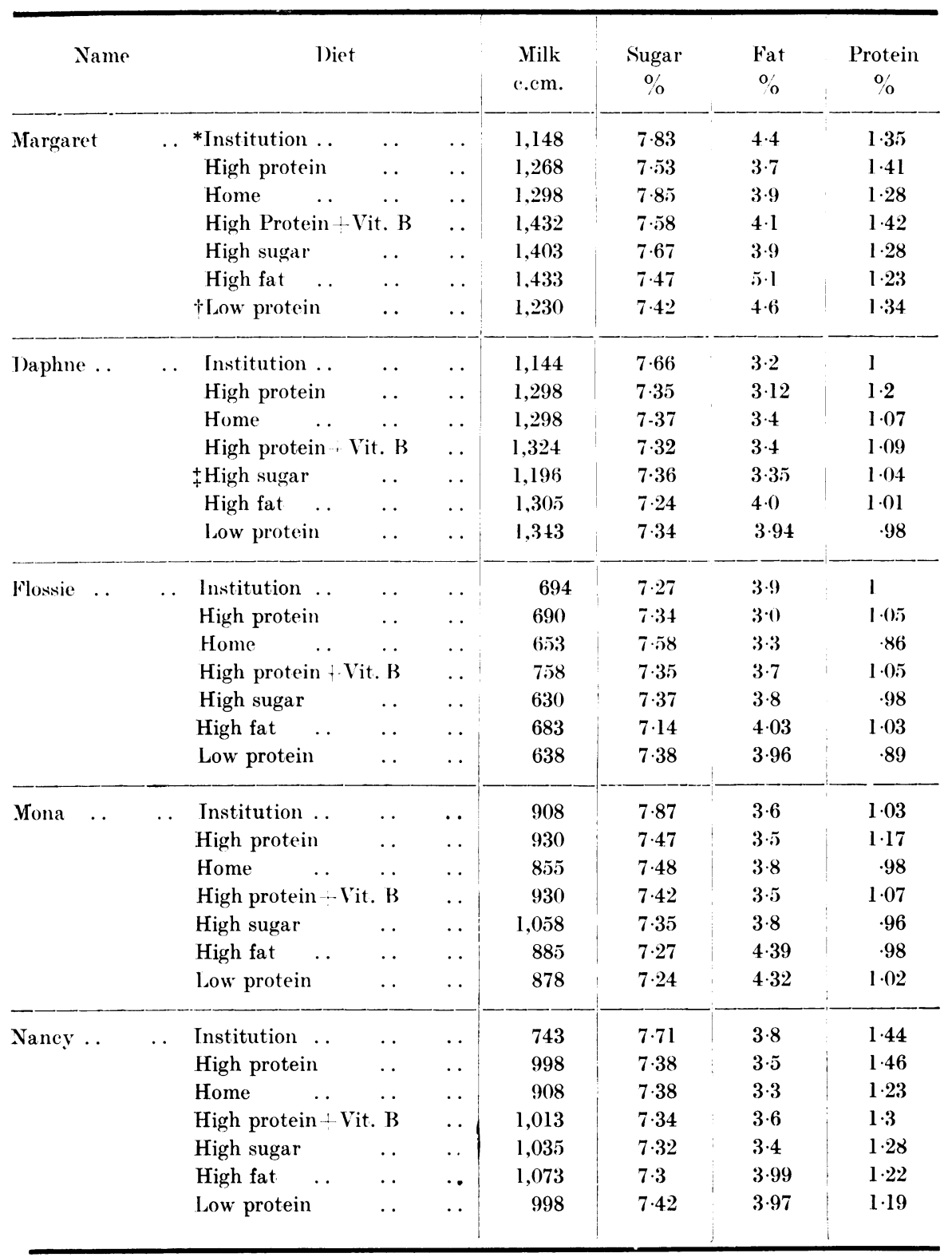

*Institution diet refers to the ordinary routine diet used in St. Mary's Home.

$\dagger$ This girl was profoundly upset by the death of her father on the day this set of samples was taken.

$\ddagger$ This girl had a bilious attack (which prevented her eating) on the day this set of samples was taken, 
TABLE 6.

DiURNal Variation in the Fat CONTENT OF THE MILK OF FIVE MOTHERS ON DIFFerent Diets.

\begin{tabular}{|c|c|c|c|c|c|c|c|c|c|c|}
\hline Name & & Diet & & & $\begin{array}{c}6 \text { a.m. } \\
\%\end{array}$ & $\begin{array}{c}10 \text { a.m. } \\
\%\end{array}$ & $\begin{array}{c}2 \text { p.m. } \\
\%\end{array}$ & $6 \underset{\%}{\text { p.m. }}$ & $\begin{array}{c}11 \text { p.m. } \\
\%\end{array}$ & $\begin{array}{c}\text { Average } \\
\%\end{array}$ \\
\hline \multirow[t]{7}{*}{ Margaret } & Institution & . & . & . & $3 \cdot 75$ & $6 \cdot 5$ & $4 \cdot 5$ & $4 \cdot 2$ & $4 \cdot 6$ & $4 \cdot 4$ \\
\hline & High protein & $\cdots$ & . & $\therefore$ & $3 \cdot 45$ & $4 \cdot 5$ & $3 \cdot 8$ & $3 \cdot 8$ & $3 \cdot 5$ & $3 \cdot 7$ \\
\hline & , , & +Vit. B. & . & $\cdots$ & $3 \cdot 9$ & $4 \cdot 75$ & $4 \cdot 2$ & $3 \cdot 65$ & $4 \cdot 3$ & $4 \cdot 1$ \\
\hline & High sugar & .. & . & $\cdots$ & $3 \cdot 7$ & $4 \cdot 85$ & $4 \cdot 75$ & $3 \cdot 25$ & $3 \cdot 75$ & $3 \cdot 9$ \\
\hline & High fat .. & .. & . & . & $5 \cdot 0$ & $7 \cdot 1 !$ & $5 \cdot 1$ & $4 \cdot 7$ & $4 \cdot 2$ & $5 \cdot 09$ \\
\hline & Low protein & .. & . & . & $4 \cdot 6$ & $5 \cdot 2$ & $4 \cdot 3$ & $4 \cdot 8$ & $4 \cdot 6$ & $4 \cdot 6$ \\
\hline & & Iverage & . & $\cdots$ & $4 \cdot 06$ & $5 \cdot 48$ & $4 \cdot 44$ & $4 \cdot 06$ & $4 \cdot 16$ & $4 \cdot 29$ \\
\hline \multirow[t]{7}{*}{ Daphne } & Institution & . & . & .. & $2 \cdot 5$ & $4 \cdot 1$ & $3 \cdot 5$ & $3 \cdot 65$ & $3 \cdot 4$ & $3 \cdot 2$ \\
\hline & High protein & . & . & $\cdots$ & $2 \cdot 4$ & $4 \cdot 4$ & $3 \cdot 3$ & $2 \cdot 9$ & $3 \cdot 1$ & $3 \cdot 12$ \\
\hline &,,$\quad$, & +Vit. B & . & . & $2 \cdot 6$ & $4 \cdot 4$ & $3 \cdot 7$ & $3 \cdot 2$ & $3 \cdot 3$ & $3 \cdot 4$ \\
\hline & High sugar & . & . & . & $2 \cdot 8$ & $5 \cdot 2$ & $4 \cdot 2$ & $3 \cdot 25$ & $1 \cdot 9$ & $3 \cdot 35$ \\
\hline & High fat .. & . & . & . & $3 \cdot 4$ & $5 \cdot 2$ & $4 \cdot 3$ & 3.9 & $3 \cdot 8$ & $4 \cdot 04$ \\
\hline & Low protein & . & . & . & $3 \cdot 2$ & $5 \cdot 0$ & $4 \cdot 2$ & $4 \cdot 0$ & 3.95 & 3.95 \\
\hline & & Average & . & . & $2 \cdot 82$ & $4 \cdot 72$ & $3 \cdot 86$ & $3 \cdot 48$ & $3 \cdot 24$ & $3 \cdot 5 \mathrm{l}$ \\
\hline \multirow[t]{7}{*}{ Flossie } & Institution & . & . & . & $2 \cdot 3$ & 4.95 & 4.65 & $4 \cdot 05$ & $2 \cdot 75$ & $3 \cdot 9$ \\
\hline & High protein & $\cdots$ & $\cdots$ & . & $3 \cdot 1$ & $3 \cdot 8$ & $3 \cdot 8$ & $2 \cdot 55$ & $2 \cdot 45$ & $3 \cdot 0$ \\
\hline &,,$\quad$, & + Vit. B & . & . & $3 \cdot 2$ & $4 \cdot 55$ & $4 \cdot 5$ & $3 \cdot 2$ & $3 \cdot 5$ & $3 \cdot 7$ \\
\hline & High sugar & . & . & . & $2 \cdot 9$ & $5 \cdot \overline{5}$ & $4 \cdot 0$ & $3 \cdot 5$ & $2 \cdot 9$ & $3 \cdot 66$ \\
\hline & High fat .. & . & . & . & $3 \cdot 7$ & $5 \cdot 5$ & $4 \cdot 6$ & $3 \cdot 4$ & $3 \cdot 2$ & 4.03 \\
\hline & Low protein & . & $\cdots$ & . & $\mathbf{2} \cdot \overline{\mathbf{5}}$ & $6 \cdot 1$ & $5 \cdot 7$ & $3 \cdot 6$ & $2 \cdot 6$ & $3 \cdot 96$ \\
\hline & & Average & - & . & $2 \cdot 95$ & $5 \cdot 06$ & $4 \cdot 54$ & $3 \cdot 38$ & $2 \cdot 9$ & $3 \cdot 71$ \\
\hline \multirow[t]{7}{*}{ Mona } & Institution & .. & . & . & $2 \cdot 4$ & $5 \cdot 0$ & $4 \cdot 3$ & $4 \cdot 3$ & $3 \cdot \overline{5}$ & $3 \cdot 6$ \\
\hline & High protein & . & . & . & $2 \cdot 4$ & $4 \cdot 8$ & $3 \cdot 1$ & $3 \cdot 7$ & $2 \cdot 5$ & $3 \cdot 3$ \\
\hline &,$\quad$, & + Vit. B & $\cdots$ & . & $2 \cdot 4$ & $5 \cdot 1$ & $3 \cdot 7$ & $3 \cdot 9$ & $3 \cdot 7$ & $3 \cdot 5$ \\
\hline & High sugar & . & . & . & $2 \cdot 8$ & $4 \cdot 75$ & $4 \cdot 4$ & $4 \cdot 3$ & $3 \cdot 5$ & $3 \cdot 8$ \\
\hline & High fat .. & . & . & . & $4 \cdot 1$ & $5 \cdot 7$ & $4 \cdot \tilde{y}$ & $4 \cdot 0$ & $3 \cdot 4$ & $4 \cdot 39$ \\
\hline & Low protein & . & $\cdots$ & $\cdots$ & $3 \cdot 7 \tilde{5}$ & $5 \cdot 7$ & $4 \cdot 4$ & $4 \cdot 1$ & $4 \cdot \tilde{3}$ & $4 \cdot 32$ \\
\hline & & Average & . & . & $2 \cdot 97$ & $5 \cdot 18$ & $4 \cdot 06$ & $4 \cdot 05$ & $3 \cdot 51$ & $3 \cdot 81$ \\
\hline & & & & 6 a.m. & 9 a.m. & 12 & 3 p.m. & 6 p.m. & 11 p.m. & Av. $\%$ \\
\hline \multirow[t]{7}{*}{ *Nancy } & Institution & . & . & $3 \cdot 6$ & $5 \cdot 1$ & $4 \cdot 2$ & $3 \cdot 35$ & $3 \cdot 6$ & $3 \cdot 15$ & $3 \cdot 8$ \\
\hline & High protein & .. & . & $3 \cdot 45$ & $4 \cdot 7$ & $3 \cdot 4$ & $3 \cdot 5$ & $3 \cdot 1$ & $2 \cdot 9$ & $3 \cdot \tilde{5}$ \\
\hline & , & +Vit. B & . & $3 \cdot 3$ & $4 \cdot 65$ & $3 \cdot 5$ & $3 \cdot 3$ & $3 \cdot 1$ & $3 \cdot 85$ & $3 \cdot 6$ \\
\hline & High sugar & . & . & $3 \cdot 3$ & $5 \cdot 0$ & $3 \cdot 7$ & $3 \cdot 1$ & $2 \cdot 7$ & $2 \cdot 9$ & $3 \cdot 4$ \\
\hline & High fat .. & .. & . & $4 \cdot 3$ & $5 \cdot 1$ & $3 \cdot 7$ & $2 \cdot 65$ & $3 \cdot 75$ & $3 \cdot 7.5$ & $3 \cdot 99$ \\
\hline & Low protein & .. & . & $3 \cdot 5$ & $5 \cdot 0$ & $4 \cdot 3$ & $3 \cdot 6$ & $3 \cdot 75$ & $3 \cdot 85$ & $3 \cdot 97$ \\
\hline & & Average & $\because$ & $3 \cdot 57$ & $4 \cdot 93$ & $3 \cdot 8$ & $3 \cdot 25$ & $3 \cdot 33$ & $3 \cdot 4$ & $3 \cdot 71$ \\
\hline
\end{tabular}

*It will be noted that with the fifth case, Nancy, the milk was expressed at three-hourly intervals throughout the day and the last specimen for the day was collected at 11 p.m. 
OBSERVATIONS ON THE MILK OF N.Z. WOMEN

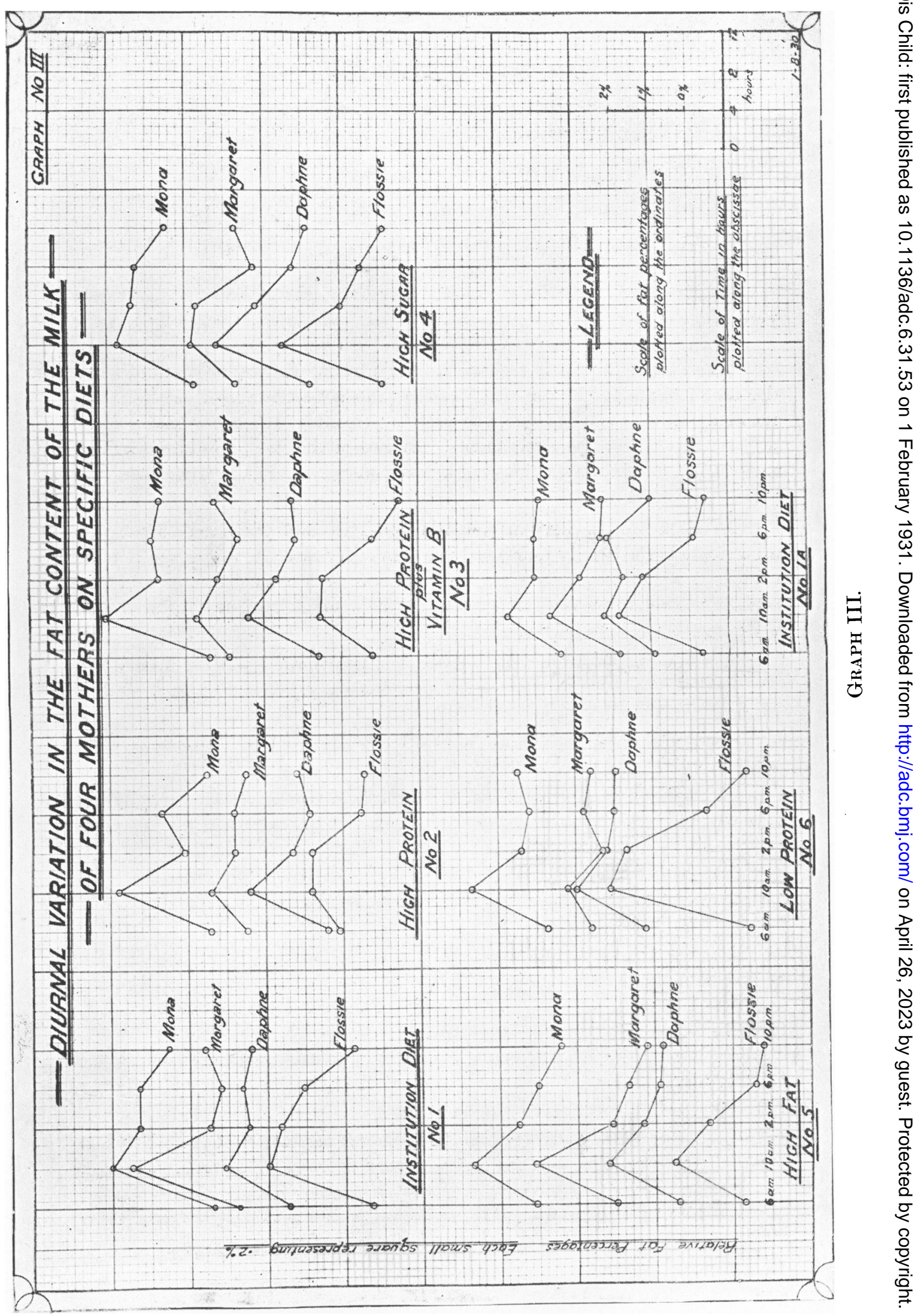




\section{Discussion of results.}

In the following summary the results obtained at the end of one week's dieting have been compared with those obtained at the end of the previous week.

1. High protein diet. (A) EFFECT ON MILK YIELD.-Four of the five mothers showed an increase in the twenty-four hourly yield compared with that obtained on the Institution diet. The average increase in amount was 108 c.cm.

(B) EfHect on composition.-There was a slight increase in the protein percentage of the milk in every case. The average increase was $\cdot 09$ per cent.

In each case the fat percentage of the milk was reduced.

When the high protein diet was followed by the Institution diet a marked decrease (averaging $\cdot 17$ per cent.) in the protein percentage of the milk was noticed. In all cases but one, the protein percentage fell below that present at the initiation of the experiments. In two of the five cases the increased milk yield noted in the previous week was maintained, but in three cases the yield was diminished.

2. High protein diet plus Vitamin B.-This diet appeared to produce an increase in the twenty-four hourly yield in every case. The average increase compared with the previous week's yield was $88.5 \mathrm{c.cm}$. The protein percentage of the milk was again increased: the average increase compared with the previous week was 1 per cent.

3. High carbohydrate Diet.-Three mothers showed a slight decrease in the yield compared with that of the previous week. One showed a marked increase.

The composition of the milk was much the same as it was when the mothers were fed on the Institution diet.

4. High fat diet.-In general the milk yield was increased very slightly as compared with the amounts obtained on the previous diet. The composition of the milk was strikingly affected. In every case, the fat percentage of the milk was increased. The average increase on the previous week's fat percentage was $\cdot 6$ per cent., and the average increase in the total amount of fat produced was 20 per cent.

5. Low protein diet.-In general there was a slight diminution in the yield compared with that obtained in the previous week. One case, Case 1*, which should, perhaps, be eliminated, showed a marked diminution in amount, and one (Case 2) actually showed an increase.

The composition of the milk was very little affected. In three cases, the protein percentage compared with that of the previous week was slightly lowered; in two cases it was actually raised.

Discussion.-The increase obtained in the fat percentage of the milk when the mothers were on a high fat diet was very definite. This finding, though taken.

*This subject was profoundly upset by the death of her father on the day the samples were 
contrary to the general opinion of dairy scientists in respect to cows, agrees with the practical observations of the Plunket nurses (Truby King system) throughout New Zealand. They state that idle mothers who over-indulge in rich fatty foods invariably have milk with a high fat content. Careful analyses of the milk of such mothers fully supports this statement. Moreover, it has been found that this high fat percentage can be reduced by systematic dieting.

The yield of milk was strikingly increased when mothers were fed on a high protein diet. This conclusion is in accordance with the results of observations made on cows. It also agrees with Hoobler's contention in respect to human milk production. The yield of milk remained either stationary or was lessened when the high protein diet was followed by the Institution diet.

The feeding of the high protein diet plus Vitamin B again produced a marked increase in the milk yield.

It is interesting to note that women who were fed on exactly similar diets showed marked differences in respect to the average fat percentage of their milk. The high fat percentage is evidently a personal characteristic as in the case of cows.

Babies receiving milks of such vastly different fat content throve equally well. When the fat percentage of the milk was raised as the result of the high fat diet given to the mother, the babies were not digestively upset. This, in a measure, may be due to the fact that the mothers were healthy and continuously engaged in manual work.

The 28 graphs illustrating the diurnal variation in the fat content of the milk of the four mothers fed on the six specific diets above mentioned, show that the generalization arrived at in Part I of this paper still holds even when there is a great variation in the diet of the mother. The fat content in every case was highest at $10 \mathrm{a} . \mathrm{m}$. and the diurnal variation in general agreement with the previous findings. Once again it was observed that the milks of high average fat content had the greatest diurnal variation.

The writer desires to thank Sir Truby King and Dr. Malcolm for their advice and assistance. Her thanks are also due to the authorities of the Karitane Home, Dunedin, and St. Mary's Anglican Home, Auckland ; and to the Dominion Analyst, Dr. McLaurin and his representatives, Messrs. L. S. James and K. M. Griffen.

\section{Summary of Part II.}

The effects of different diets on the milk secretion of women have been studied.

1. The feeding of a high fat diet to nursing mothers was found to increase the fat percentage of their milk.

2. The feeding of a high protein diet and a high protein plus Vitamin-B diet was found to increase the milk yield. 
3. The composition of the milk was not appreciably affected by great changes in the constituents of the diet other than fat.

4. The results of 28 determinations of the diurnal variation in the fat content of human milk are tabulated and recorded graphically. The results support the generalization arrived at in Part I of this paper.

\section{REFERENCES.}

1. Reiset, Gorup Besanez, Lehrbuch der Physiologisrhen Chemie, 1878, 428.

2. Helbich, Monatshr f. Kinderh., Leipsic, 1911, X, 649.

3. Dennis, W., \& Talbot, F. B., Amer. J. Dis. Child., Chicago, 1919, XVIII, 93.

4. Myers, B., Brit. J. Ch. Dis., Lond., 1927, XXIV, 256.

5. Gaines, W. L., Am. J. Physiol., Baltimore, 1915, XXXVIII, 285.

6. Richmond, H. 1)., Dairy Chemistry, 1920, 319.

7. Wardlaw, H. S. H., \& Dart, E. E. P., Austral. J. Exp. Biol. and Med. S'c., Adelaide, 1926, III, 130.

8. Meigs, E. B., Physiol. Revieus, Baltimore, 1922, II, 204.

9. Engel, \& Plant, München med. Wchnschr., Münich, 1906, LIII, 1158.

10. Czerny, \& Keller, Des Kindes, Leipsig, 1906, I, 407.

11. Hoobler, B., Am. J. Dis. Child., Chicago, 1917, XIX, 105.

12. Bell, M., Biol. J., 1928, LXXX.

13. Sure, B., Amer. J. Dis. Child., ('hicago, 1914, VII, 445. 